\title{
Molecular Identification of Delphinids and Finless Porpoise (Cetacea) from the Arabian Sea and Bay of Bengal
}

\author{
P. JAYASANKAR ${ }^{1}$, B. ANOOP ${ }^{2}$, VIVEKANANDAN ${ }^{3}$, M. RAJAGOPALAN ${ }^{4}$, K.M.M. YOUSUF ${ }^{5}$ \\ P. REYNOLD ${ }^{6}$, P.K. KRISHNAKUMAR ${ }^{7}$, PL. KUMARAN ${ }^{8}$, V.V. AFSAL ${ }^{9}$, \& ANOOP A. KRISHNAN ${ }^{10}$ \\ ${ }^{1}$ Central Marine Fisheries Research Institute, PB No. 1603, Cochin 682 018, Kerala, India. ${ }^{1}$ Current address: Central Institute of \\ Freshwater Aquaculture, Kausalyaganga, Bhubaneswar- 751 002, India. E-mail: jayasankarp@vsnl.com \\ ${ }^{2}$ Central Marine Fisheries Research Institute, PB No. 1603, Cochin 682 018, Kerala, India \\ ${ }^{3}$ Central Marine Fisheries Research Institute, PB No. 1603, Cochin 682 018, Kerala, India \\ ${ }^{4}$ Madras Research Centre of CMFRI,75, Santhome High Road, Chennai 600028 \\ ${ }^{5}$ Central Marine Fisheries Research Institute, PB No. 1603, Cochin 682 018, Kerala, India \\ ${ }^{6}$ Central Marine Fisheries Research Institute, PB No. 1603, Cochin 682 018, Kerala, India \\ ${ }^{7}$ Marine Studies Section, Centre for Environment \& Water-RI, King Fahd University of Petroleum \& Minerals, Dhahran 31261, Saudi \\ Arabia \\ ${ }^{8}$ AP 454, 22nd Street Thiruvalluvar Kudiyiruppu Anna Nagar, Chennai 600040, India \\ ${ }^{9}$ Central Marine Fisheries Research Institute, PB No. 1603, Cochin 682 018, Kerala, India \\ ${ }^{10}$ Export Inspection Agency, Marol, Andheri (East), Mumbai 400 093, India
}

\begin{abstract}
The exact number of extant delphinid species from seas around India is still debated and the lack of adequate field keys and reliable inventory has resulted in misidentification of several species. As a part of a project to develop a molecular taxonomy of cetaceans from this region, partial sequences of mtDNA cytochrome $b$ were generated from accidentally caught/stranded delphinids and finless porpoise. Species were identified by phylogenetic reconstruction of sample sequences with the reference sequences available in portals GenBank (NCBI) and the web-based program DNA Surveillance. A comparison was made with the homologous sequences of corresponding species from other seas of the world. Our molecular investigations allowed us to identify five species of cetaceans from Indian coasts, including Delphinus capensis, previously reported as $D$. delphis. We detected unique haplotypes in Indo pacific humpbacked dolphin (Sousa chinensis; $\mathrm{n}=2$ ) and finless porpoise (Neophocaena phocaenoides; $\mathrm{n}=12$ ) from Indian coast. On the other hand, some haplotypes were shared with other regional populations in spinner dolphin (Stenella longirostris; $\mathrm{n}=16$ ) and bottlenose dolphin (Tursiops aduncus; $\mathrm{n}=3$ ). Common dolphins (Delphinus capensis; $\mathrm{n}=2$ ) had both unique and shared haplotypes including one highly divergent sequence.
\end{abstract}

Key words: Delphinids, finless porpoise, mitochondrial DNA, molecular taxonomy, haplotypes

\section{Introduction}

Taxonomy is fundamental to conservation efforts of marine mammals and the units on which conservation is based are determined largely by species designation. Ambiguous identification of species can lead to erroneous conclusions, such as loss of genetic variability and unwitting extinction of species. In cetaceans, morphological features are often subtle and difficult to compare because of the rarity of specimens or widespread distributions and regional variation (Reeves et al. 2004). Identifying the geographical variants of recognized species of delphinids and phocoenids is even more difficult using the conventional approaches and in this context molecular genetics can provide significant contributions to taxonomic understanding of inter and intra- 
specific variations for conservation and management purposes (Rosel et al. 1999, LeDuc et al. 1999, Dizon et al. 2000, Reeves et al. 2004, Amaral et al. 2007). At higher taxonomic levels, it has become possible to generate useful molecular genetic data, especially DNA sequences, supported by theoretical advances and computer programs, leading to reinvestigation of phylogenetic issues involving cetaceans (Milinkovitch et al. 2002).

DNA sequence analysis has become a powerful tool for conservation - particularly in identifying the source of samples thought to be derived from threatened or endangered species. Only minute amounts of DNA are required, allowing for remote sampling. PCR-based techniques technically are simple and rapid, making them practical for conservation and population studies. In cetaceans, the technique is effective in the forensic identification of commercial products and verification of trade records as well as for identifying ambiguous beach-cast specimens (Reeves et al. 2004; Dalebout et al., 2007). Illegal trade in animal/plant products is commonly practiced in some of the Asian countries, where some of the endangered species are marketed in the guise of ones approved by authorized bodies such as, the International Whaling Commission (IWC) (Dizon et al. 2000).

The number of extant global species of cetaceans is debated (Rice 1998; Perrin et al. 2002; Baker et al. 2003). Cetacean systematics, particularly that of delphinids, is rapidly changing for a variety of reasons, including advances in analytical techniques, application of molecular markers, and increases in the amount of material available; and revisions are expected to continue at all levels (Milinkovitch et al. 2002).

Research on cetaceans in India has been restricted to reporting on their incidental catches in fishing nets or beach-cast samples. Spinner dolphin (Stenella longirostris), bottlenose dolphin (Tursiops aduncus), Indo pacific humpbacked dolphin (Sousa chinensis) and common dolphin (Delphinus capensis) are the commonly encountered delphinids and finless porpoise, the only known representative of phocoenids in India. These species seem to be residents or regular visitors to the coastal areas, thereby facing higher risks of either entanglement in fishing nets other than the other offshore species.

In Indian seas, however, it is unclear still as to how many species of cetaceans exist due to the absence of any dedicated survey to assess their abundance (Sathasivam 2004). Though the extant delphinid species number in Indian seas is estimated to be 13, it could probably be more (Kumaran 2002). Lack of adequate field keys and reliable inventory has resulted in several cases of misidentification. There has been no effort so far to use molecular tools for the identification of cetaceans from the Indian seas.

Against this background, the present study was carried out, with a view to generating species-diagnostic mitochondrial DNA (mtDNA) sequences for molecular identification of delphinids and finless porpoise from the Indian seas. Because of its small effective population size and its rapid rate of evolution compared to nuclear DNA, mtDNA has been the most widely used molecular marker in phylogenetic and population genetic analysis of marine mammals (Reeves et al. 2004). A number of mtDNA sequences of cetaceans are available in the two databases, GenBank (NCBI) and DNA Surveillance. With the use of these databases, molecular taxonomic identification of the species is possible from carcass of ambiguous stranded specimens or even from tissues of unknown samples.

The present study represents an initial attempt to develop a database of nucleotide sequences for future cetacean research in addition to confirming the identity of delphinids and finless porpoise collected around India using standard molecular techniques and to make a comparison of Indian haplotypes with those of the corresponding species from other geographical seas. The smaller numbers analyzed in most of the cases will not probably resolve the species identity crisis; but it is expected to contribute for a comparison of the species from India with those of global occurrence.

\section{Material and methods}

Sampling. The locations of marine mammal sample collection are shown in Fig.1 and particulars of the samples including the accession numbers of mtDNA cytochrome $b$ (hereafter mentioned as CYB) partial sequences deposited in GenBank are given in Table 1. Skin samples were obtained from dolphins and por- 
poises killed incidentally in coastal (or offshore) fisheries and identified initially as Stenella longirostris $(\mathrm{n}=16)$, Tursiops aduncus $(\mathrm{n}=3)$, Delphinus capensis $(\mathrm{n}=2)$, Sousa chinensis $(\mathrm{n}=2)$, and Neophocaena phocaenoides $(\mathrm{n}=12)$. The tissue was taken either from the dorsal fin and stored in $70 \%$ ethanol for subsequent analysis. In order to avoid contamination, sterilized forceps, blades and surgical gloves were used. Although skulls or skeletons of the specimens studied were not stored at any institution, photographs representing all the five species were made for identification purpose (Fig. 2).

TABLE 1. Particulars of the delphinid and finless porpoise samples examined during the present study.

\begin{tabular}{|c|c|c|c|c|c|}
\hline Sl No. & Species & $\begin{array}{l}\text { Place and date of } \\
\text { sample collection }\end{array}$ & Sample code & $\begin{array}{l}\text { GenBank accession } \\
\text { numbers of CYB }\end{array}$ & $\begin{array}{l}\text { Haplotype code used } \\
\text { in the present study }\end{array}$ \\
\hline 1 & Tursiops aduncus & Vizhinjam (5.11.04) & Viz1 & DQ232769 & IndTa1 \\
\hline 2 & T. aduncus & Chennai (4.10.04) & $\mathrm{CHO} 4$ & DQ270184 & IndTa1 \\
\hline 3 & T. aduncus & Chennai (12.10.04) & CHO8 & EF203434 & IndTa2 \\
\hline 4 & Stenella longirostris & Kakinada (20.09.04) & VRC/Dol/05 & DQ270182 & IndS19 \\
\hline 5 & S. longirostris & Kakinada (20.09.04) & VRC/Dol/04 & EF203445 & IndS15 \\
\hline 6 & S. longirostris & Kakinada (20.09.04) & VRC/Dol/06 & EF057433 & IndS19 \\
\hline 7 & S. longirostris & Chennai (4.10.04) & $\mathrm{CHO} 2$ & EF203446 & IndS12 \\
\hline 8 & S. longirostris & Chennai (4.10.04) & $\mathrm{CHO} 3$ & EF203447 & IndS11 \\
\hline 9 & S. longirostris & Mangalore (8.9.04) & MNG 3 & EF203448 & IndSl3 \\
\hline 10 & S. longirostris & Chennai (4.10.04) & CH6 & EF057434 & IndS111 \\
\hline 11 & S. longirostris & Chennai (4.10.04) & $\mathrm{CHO} 7$ & DQ232770 & IndS110 \\
\hline 12 & S. longirostris & Chennai (26.10.04) & CH9 & EF057436 & IndS18 \\
\hline 13 & S. longirostris & Chennai (26.10.04) & $\mathrm{CH} 10$ & EF203449 & IndS12 \\
\hline 14 & S. longirostris & Chennai (26.10.04) & CH11 & EF203450 & IndS13 \\
\hline 15 & S. longirostris & Chennai (26.10.04) & $\mathrm{CH} 13$ & EF446614 & IndS12 \\
\hline 16 & S. longirostris & Chennai (26.10.04) & $\mathrm{CH} 17$ & EF057437 & IndS17 \\
\hline 17 & S. longirostris & Chennai (26.10.04) & CH18 & EF057438 & IndS16 \\
\hline 18 & S. longirostris & Chennai (26.10.04) & $\mathrm{CH} 19$ & EF446613 & IndS14 \\
\hline 19 & S. longirostris & Cochin (15.9.07) & COK1 & EU204619 & IndS13 \\
\hline 20 & Delphinus capensis (?) & Kakinada (23.08.04) & VRC/Dol/03 & DQ320765 & IndDc2 \\
\hline 21 & D. capensis tropicalis & Malpe (24.02.06) & MNG18 & EF061405 & IndDc1 \\
\hline 22 & Sousa chinensis & Gangoli (24.11.05) & MNG 4 & DQ364689 & IndSc1 \\
\hline 23 & S. chinensis & Mangalore (24.12.05) & MNG16 & EF057445 & IndSc1 \\
\hline 24 & Neophocaena phocaenoides & Gangoli (25.11.05) & MNG 5 & EF203435 & IndNp1 \\
\hline 25 & N. phocaenoides & Gangoli (25.11.05) & MNG6 & EF203436 & IndNp1 \\
\hline 26 & N. phocaenoides & Gangoli (25.11.05) & MNG 7 & DQ364692 & IndNp1 \\
\hline 27 & N. phocaenoides & Gangoli (25.11.05) & MNG 8 & DQ364691 & IndNp2 \\
\hline 28 & N. phocaenoides & Gangoli (25.11.05) & MNG 9 & EF203437 & IndNp1 \\
\hline 29 & N. phocaenoides & Gangoli (25.11.05) & MNG 10 & EF203438 & IndNp1 \\
\hline 30 & N. phocaenoides & Gangoli (25.11.05) & MNG 11 & EF203439 & IndNp1 \\
\hline 31 & N. phocaenoides & Gangoli (25.11.05) & MNG 12 & EF203440 & IndNp1 \\
\hline 32 & N. phocaenoides & Malpe (17.11.05) & MNG 13 & EF203441 & IndNp1 \\
\hline 33 & N. phocaenoides & Malpe (5.11.05) & MNG 14 & EF203442 & IndNp1 \\
\hline 34 & N. phocaenoides & Mangalore (1.12.05) & MNG 15 & EF203443 & IndNp1 \\
\hline 35 & N. phocaenoides & Mangalore (2.1.2006) & MNG 17 & EF203444 & IndNp1 \\
\hline
\end{tabular}




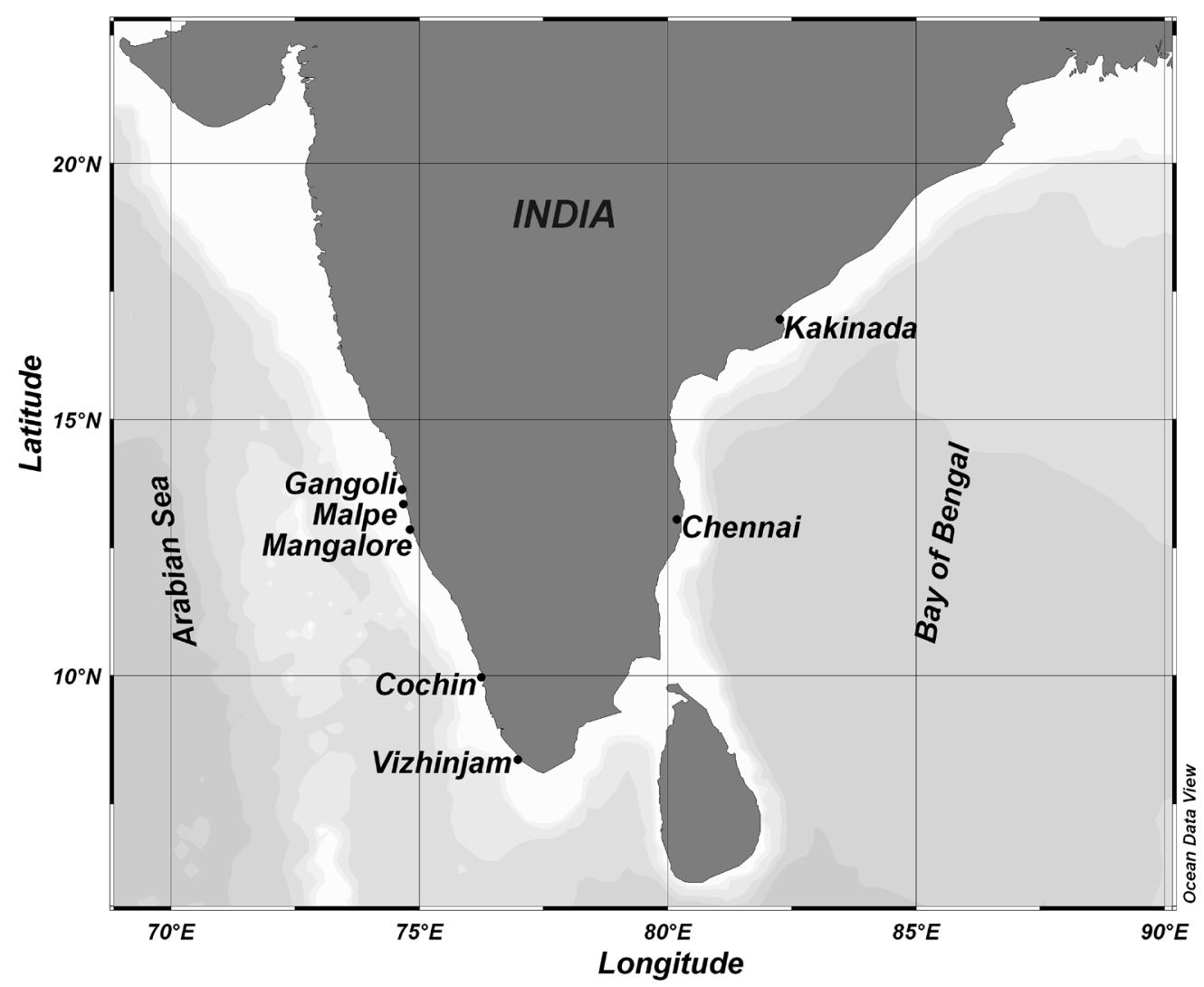

FIGURE 1. Locations where delphinids and finless porpoise were sampled in the present study

DNA Extraction, PCR and Sequence Analysis. Total genomic DNA was extracted using the standard phenol-chloroform method (Sambrook et al. 1989). Amplification reactions were performed on either PE24 (Applied Biosystems Inc.) or PTC100 (MJ Research) thermocycler in a total volume of $25 \mu$ l containing 10$100 \mathrm{ng}$ of extracted genomic DNA template, $10 \mathrm{mM}$ of Tris- $\mathrm{HCl}\left(\mathrm{pH} \mathrm{9.0),} 50 \mathrm{mM} \mathrm{KCl}, 1.5 \mathrm{mM} \mathrm{MgCl}{ }_{2}\right.$, $0.01 \%$ gelatin, $240 \mu \mathrm{M}$ each of dATP, dTTP, dCTP and dGTP, $1 \mathrm{U}$ of Taq DNA polymerase and 10-25 pM each of forward and reverse primers. The temperature profile for the amplifications was an initial denaturation $\left(94^{\circ} \mathrm{C}\right.$ ) for $2 \mathrm{~min}$ followed by 35 cycles of $94^{\circ} \mathrm{C}$ for $1 \mathrm{~min}, 54^{\circ} \mathrm{C}$ for $2 \mathrm{~min}$ and $72^{\circ} \mathrm{C}$ for $1 \mathrm{~min}$ and a final extension of $72^{\circ} \mathrm{C}$ for $7 \mathrm{~min}$. Primers for the mitochondrial DNA cytochrome $b$ region used were from Palumbi (1996), namely GLUDG-L (5'-TGACTTGAARAACCAYCGTTG-3') and CB2-H (5'-CCCTCAGAATGATATTTGTCCTCA-3').

Quality of the PCR products was checked on 1.5\% agarose gel. They were purified using the KT 62 Genei quick PCR purification kit. Cycle sequencing reaction was performed on a ABI 3100 PE automated capillary sequencer using the forward primer, reaction buffer and the fluorescently labeled dye terminators for required number of cycles at specific temperatures.

The sequences were first edited using BioEdit ver 7.0.5.3 (Hall 1999), aligned using the computer software Clustal W multiple alignment (Thompson et al. 1994) and corrected by eye. Primer and ambiguous sequences were deleted. CYB nucleotide sequences were translated to amino acid sequences using software Primer Premier ver 5.00 for submission in GenBank.

Species Identification. Morphological identification of the delphinids and finless porpoise was based on Rice (1998). Molecular identification was done in two steps: (1) sequence similarity search under BLAST (Basic Local Alignment Search Tool) as implemented in GenBank (www.ncbi.nlm.nih.gov). (2) once it was confirmed that the tissue sample was from a cetacean, the species identity was searched within DNA Surveillance (www.cebl.auckland.ac.nz:9000/), which contains a comprehensive database of mitochondrial DNA 
sequences from mostly validated species by taxonomists. (Ross et al. 2003). Most sequences in this interactive portal were included only if the specimen had been expertly identified and diagnostic skeletal material or photographic records were collected (Dizon et al. 2000). The purpose of checking the higher taxa of the unknown sample with BLAST search is important because if it does not belong to the order Cetacea, results of the phylogenetic identification could be misleading. The sequences, after their confirmation, were submitted to GenBank.

Haplotype Comparisons. In order to perform haplotype comparisons, 7 homologous CYB sequences of spinner dolphin from GenBank were added to the sequences obtained in the present study. Similarly CYB sequences of bottlenose dolphin $(n=4)$, common dolphin $(n=7)$, Indo pacific humpbacked dolphin $(n=3)$ and finless porpoise $(n=2)$ were also added from the GenBank for haplotype comparison.

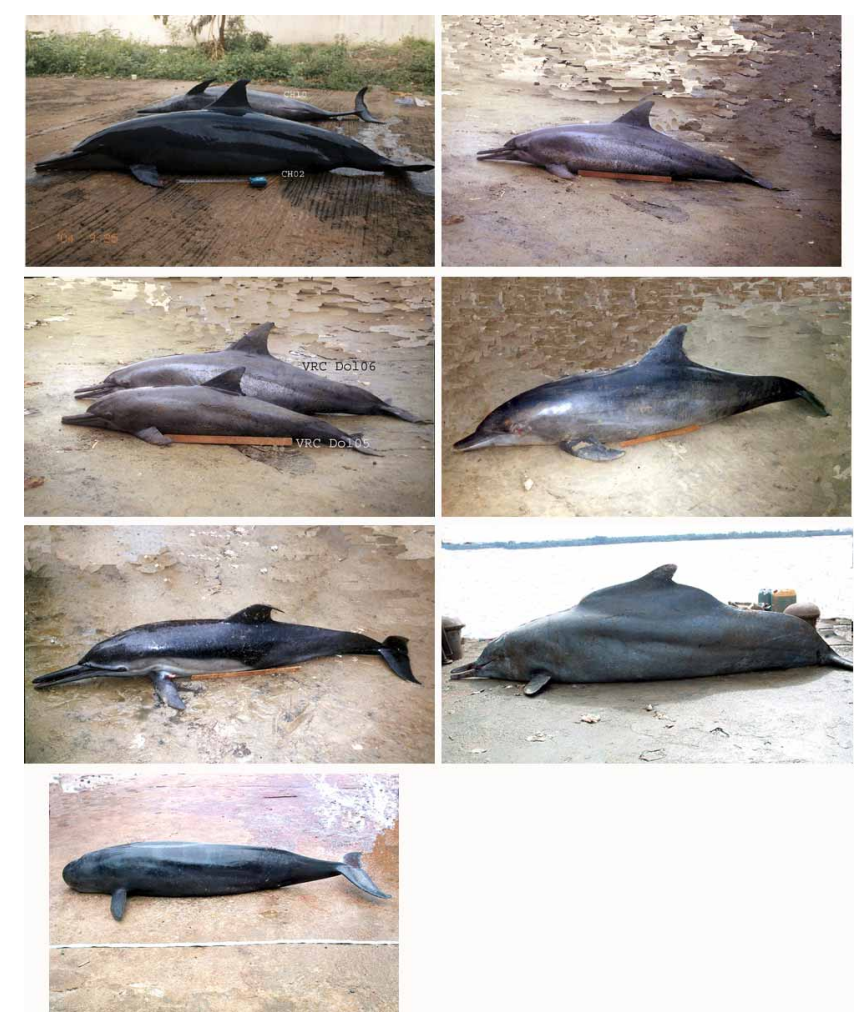

FIGURE 2. Illustrations of the cetaceans sampled in this study. a-Stenella longirostris: specimens CH02 \& CH10 (haplotype code: IndS12); b-Stenella longirostris: specimen Dol04 (haplotype code: IndS15); C—Stenella longirostris: specimens Do105 \& Dol06 (haplotype code: IndS19); d-Tursiops aduncus: specimen CH08 (haplotype code: IndTa2); e-Delphinus capensis (?): specimen Dol03 (haplotype code: IndDc2); f-Sousa chinensis: specimen MNG4 (haplotype code: IndSc1); $\mathbf{g}$ - Neophocaena phocaenoides: specimen MNG5 (haplotype code: IndNp1).

\section{Results}

MtDNA Sequence Products. Primers GLUDG-L/CB2-H generated robust PCR product of mtDNA CYB gene in all the five species with readable sequences ranging from 421 to $530 \mathrm{bp}$.

Spinner dolphin (Stenella longirostris). Spinner dolphin was the most common species in the present collections, with 14 specimens coming from the east coast (Kakinada and Chennai) and two from the west coast (Mangalore and Cochin). We found 11 haplotypes, one of which (haplotype IndS11) matched a reference sequence from the Timor Sea (GenBank AF084103) and another (haplotype IndS12) matched a reference sequence from an unknown location (GenBank X92524; Arnason and Gullberg, 1996). Alignment with 7 


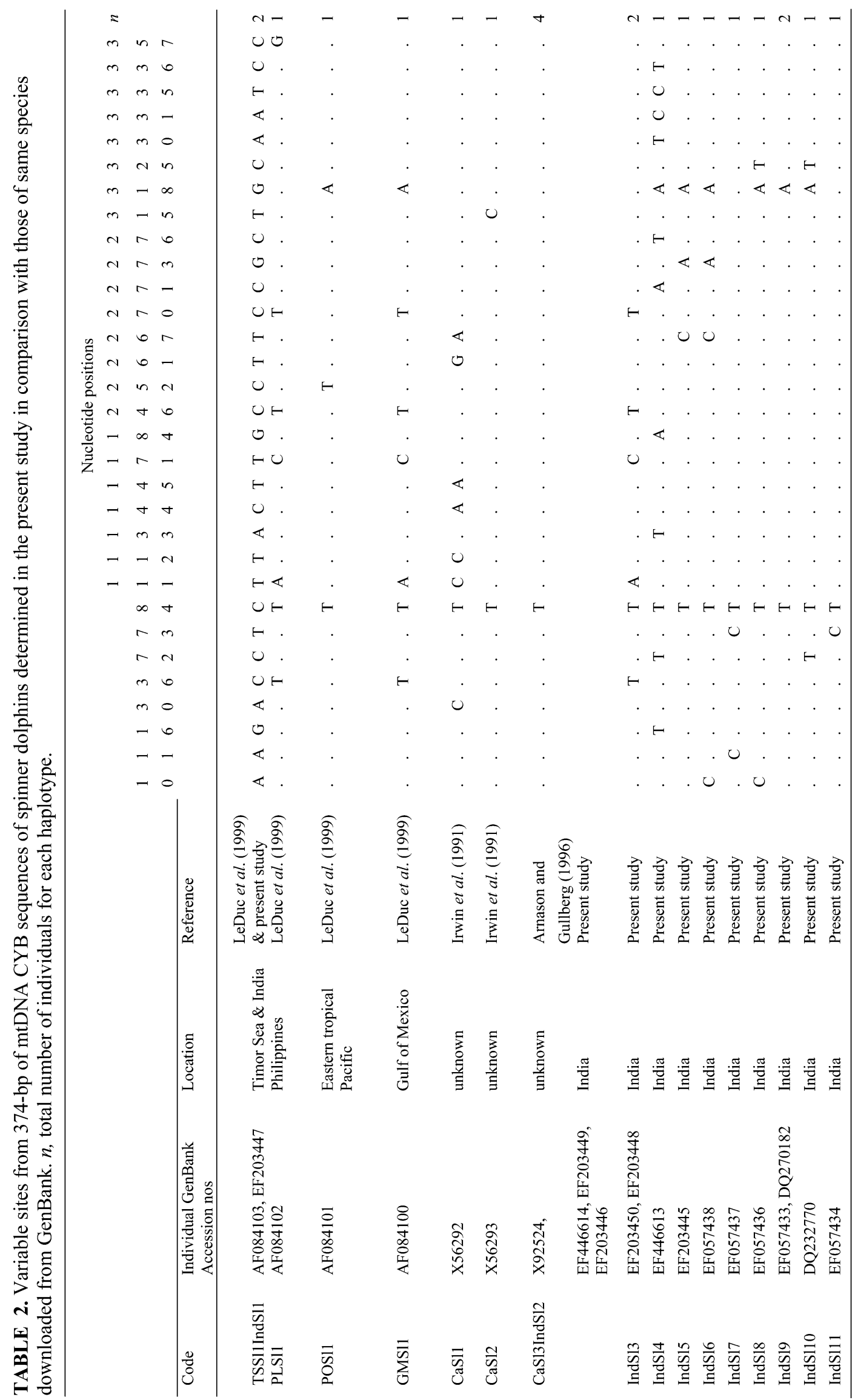


sequences downloaded from GenBank showed 29 variable sites (22 transitions, 7 transversions and 2 both transition and transversion) (Table 2). Pictures of the individuals representing the three haplotype clusters obtained using DNA Surveillance (data not shown) are given in Figs 2a-c.

Bottlenose dolphin (Tursiops aduncus) (Fig. 2d). Two haplotypes of bottlenose dolphin were identified, one of which was the same as that of a Japanese sample (AF425253). Alignment with five samples downloaded from GenBank showed 7 variable sites (5 transitions and 2 transversions) (Table 3 ).

TABLE 3. Variable sites from 346-bp of mtDNA CYB sequences of bottlenose dolphins determined in the present study in comparison with those of same species downloaded from GenBank. $n$, total number of individuals for each haplotype.

\begin{tabular}{|c|c|c|c|c|c|c|c|c|c|c|c|}
\hline & & & & \multicolumn{8}{|c|}{ Nucleotide positions } \\
\hline & & & & \multirow{3}{*}{$\begin{array}{l}2 \\
6\end{array}$} & \multirow{3}{*}{$\begin{array}{l}4 \\
0\end{array}$} & \multirow{3}{*}{$\begin{array}{l}5 \\
0\end{array}$} & \multirow{3}{*}{$\begin{array}{l}5 \\
5\end{array}$} & \multirow{3}{*}{$\begin{array}{l}2 \\
4 \\
4\end{array}$} & \multirow{3}{*}{$\begin{array}{l}2 \\
5 \\
7\end{array}$} & \multirow{3}{*}{$\begin{array}{l}2 \\
9 \\
2\end{array}$} & \multirow{4}{*}{1} \\
\hline & & & & & & & & & & & \\
\hline & & & & & & & & & & & \\
\hline Code & $\begin{array}{l}\text { Individual GenBank } \\
\text { accession nos. }\end{array}$ & Location & Reference & & & & & & & & \\
\hline SATa1 & AF084092 & S Africa & Leduc et al. (1999) & G & A & $\mathrm{T}$ & $\mathrm{C}$ & G & $\mathrm{T}$ & $\mathrm{T}$ & 1 \\
\hline JKTa1JaTa1 & AF084091, AF425254 & Jakarta, Indonesia \& & Leduc et al. (1999) & . & . & $\mathrm{C}$ & $\mathrm{T}$ & A & $\mathrm{C}$ & $\mathrm{C}$ & 2 \\
\hline & & $\begin{array}{l}\text { Japan: Western } \\
\text { Kyushu }\end{array}$ & Shirakihara et al. (2003) & & & & & & & & \\
\hline JATa2IndTa1 & AF425253, & $\begin{array}{l}\text { Japan: Western } \\
\text { Kyushu }\end{array}$ & Shirakihara et al. (2003) & . & . & $\mathrm{C}$ & $\mathrm{T}$ & . & $\mathrm{C}$ & $\mathrm{C}$ & 3 \\
\hline & DQ270184, DQ232769 & \& India & Present study & & & & & & & & \\
\hline IndTa2 & EF203434 & India & Present study & $\mathrm{T}$ & $\mathrm{C}$ & $\mathrm{C}$ & $\mathrm{T}$ & . & $\mathrm{C}$ & $\mathrm{C}$ & 1 \\
\hline
\end{tabular}

Long-beaked common dolphin (Delphinus capensis) (Fig. 2e). We identified 2 haplotypes, one of which was the same as that of an Indian Ocean specimen available in GenBank (AF084088). When compared to sequences downloaded from GenBank, 28 variable sites (14 transitions, 12 transversions and 2 transitions/ transversions) were identified (Table 4). The haplotype IndDc2 of the present study exhibited maximum sequence divergence from the rest, even from the other Indian haplotype IndDc1 (5.9\% divergence).

Indopacific humpbacked dolphin (Sousa chinensis) (Fig. 2f). We detected one single haplotype for the two individuals studied. Using the sequences downloaded from GenBank, 15 variable sites (12 transitions and 3 transversions) were identified (Table 5). The Indian haplotype of S. chinensis was highly divergent from the South African and Hong Kong haplotypes.

Finless porpoise (Neophocaena phocaenoides) (Fig. 2g). Finless porpoise was the second most abundant species collected during the present investigation with all the individuals obtained from the west coast of India. Two haplotypes were identified in the present study. When aligned with sequences from GenBank, only 5 variable sites (all five transitions) were identified (Table 6).

\section{Discussion}

Of the five species of delphinids identified using molecular taxonomy in the present study, four were recorded by earlier workers from Indian seas, except Delphinus capensis, which was reported previously as D. delphis (Kumaran 2002). Marine mammals in terms of number of species and individuals are abundant in the southwest coast of India, Gulf of Mannar and southern Sri Lanka. Though accurate estimates are not available, it appears that a few thousand dolphins and porpoise may die of non-targeted fishing every year (Yousuf et al., 

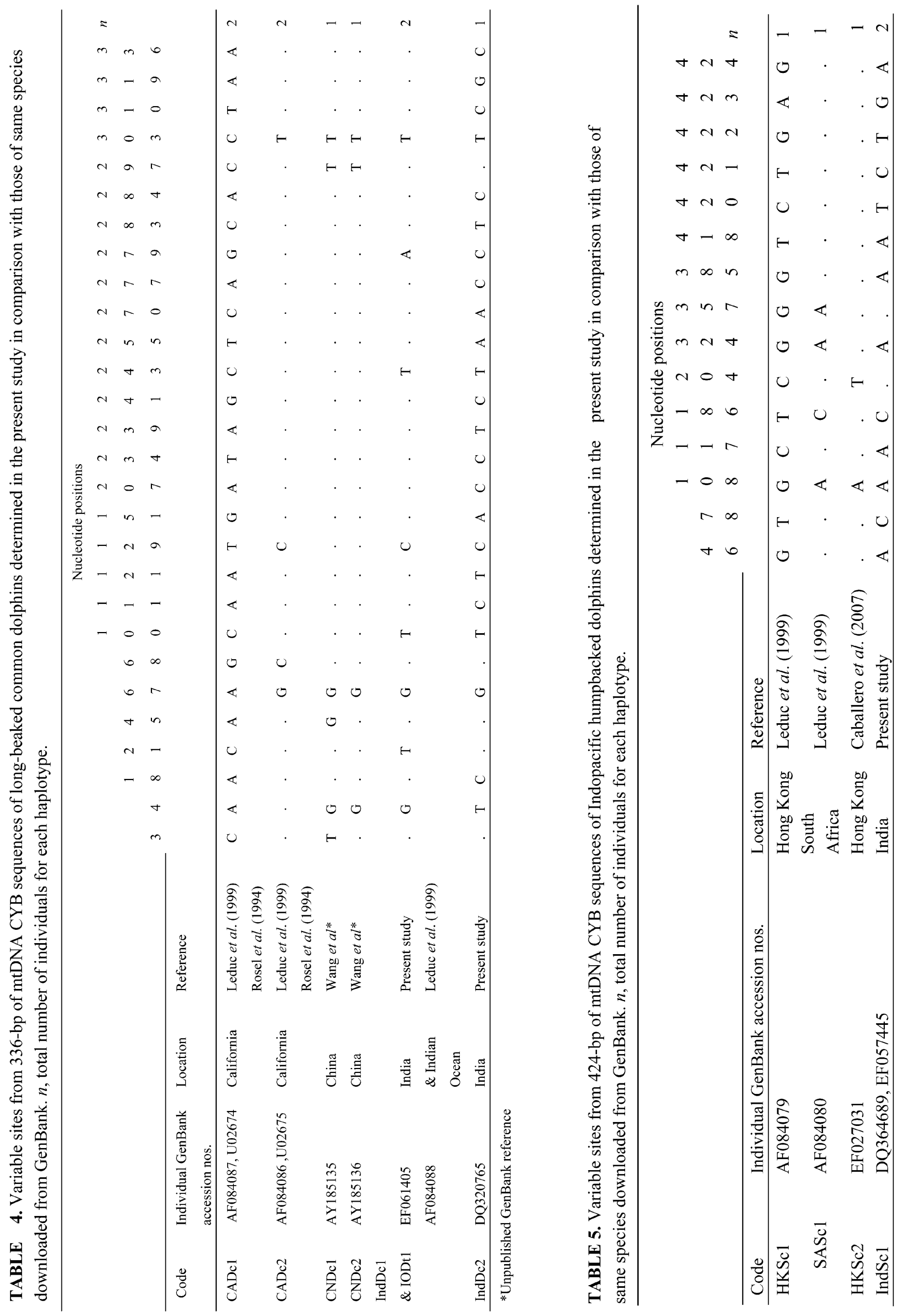
2008). For addressing all issues impacting the cetaceans around India, their unambiguous identification, inventory and cataloguing are essential. Kumaran (2002) has pointed out several cases of misidentification of cetaceans committed by earlier Indian workers who solely depended on conventional tool of taxonomy molecular approach can help address the species identity through standardized comparisons.

As many as 11 haplotypes were observed in S. longirostris of Indian seas, indicating high genetic variability in the species. The taxonomy of Stenella is a matter of ongoing debate and presence of multiple subspecies of S. longirostris (Perrin 1990, Perrin et al 1999) could further complicate the scenario. DNA Surveillance itself recommends caution on phylogeny-based molecular identification.

The earlier published studies from India have mentioned the bottlenose dolphin species as Tursiops truncatus (Sathasivam 2004). However, it is now evident that the species of bottlenose dolphin which is often killed accidentally in the coastal gillnet fisheries is likely to be T. aduncus. We have sighted T. truncatus in the oceanic waters off Indian coasts while undertaking many cruises (B.A., K.M.M.Y., V.V.A. and A.A.K.; data not shown). T. truncatus is larger than T. aduncus and has a shorter beak. All the three specimens collected in the present study showed closest genetic proximity to T. aduncus.

All the earlier workers have mentioned the species of common dolphin from Indian seas as Delphinus delphis (Sathasivam 2004). But the species encountered in the present study had a fairly long beak and based on the morphological features as well as mtDNA sequencing, is identified here as either Delphinus capensis or D. tropicalis. Jefferson \& Van Waerebeek (2002) concluded on the basis of morphological comparisons that the tropicalis form should be regarded as a subspecies of D. capensis and suggested that the present species is most likely to be Delphinus capensis tropicalis (T.A. Jefferson, pers. comm.). While one of the haplotypes in the present study had absolute genetic similarity with the one reported earlier by Leduc et al. (1999), the other one was extremely divergent (long branch) and in DNA Surveillance was placed in a cluster grouping two short-beaked common dolphins as well as one tropicalis form. We have decided to name this specimen as Delphinus capensis with an interrogation mark. Although the possibility of contamination of this sample is unlikely, sequencing of a nuclear pseudogene, which came about as a replication of cytochrome $b$ cannot be ruled out (Mirol et al. 2000).

TABLE 6. Variable sites from 373-bp of mtDNA CYB sequences of finless porpoise determined in the present study in comparison with those of the same species downloaded from GenBank. $n$,total number of individuals for each haplotype.

\begin{tabular}{|c|c|c|c|c|c|c|c|c|c|}
\hline & & & & & leot & de $\mathrm{p}$ & siti & & \\
\hline & & & & & 1 & 2 & 2 & 3 & \\
\hline & & & & 2 & 0 & 0 & 2 & 7 & \\
\hline & & & & 3 & 8 & 6 & 4 & 1 & $\mathrm{n}$ \\
\hline Code & Individual GenBank accessions & Location & Reference & & & & & & \\
\hline ChnNp1 & AF334489, NPU09680 & China & Hamilton et al. (2001) & $\mathrm{T}$ & $\mathrm{C}$ & $\mathrm{C}$ & $\mathrm{C}$ & G & 2 \\
\hline & & & Rosel et al. (1995b) & & & & & & \\
\hline IndNp1 & $\begin{array}{l}\text { EF203444, EF203443, } \\
\text { EF203442, }\end{array}$ & India & Present study & $\mathrm{C}$ & $\mathrm{T}$ & $\mathrm{T}$ & $\mathrm{T}$ & A & 11 \\
\hline & $\begin{array}{l}\text { EF203441, EF203440, } \\
\text { EF203439 }\end{array}$ & & & & & & & & \\
\hline & EF203438, EF203437, EF20343 & & & & & & & & \\
\hline & EF203435, DQ364692 & & & & & & & & \\
\hline IndNp2 & DQ364691 & India & Present study & $\mathrm{C}$ & $\mathrm{T}$ & . & $\mathrm{T}$ & A & 1 \\
\hline
\end{tabular}


The present samples of Indopacific humpbacked dolphins were all from the West coast of India, hence we could not verify the possible genetic differences between the West and East coastal forms of this species. Populations along the two coasts are reported to differ markedly in their body color and size of the dorsal hump (Sutaria and Jefferson 2004).

The identity of many delphinid species from Indian seas is as confusing as it is elsewhere. The present study was restricted to only coastal collections, taken as fisheries by-catch. Some of the Indian haplotypes were comparable to those segregated far apart geographically; but not comparable to those in the same locality. This is perhaps because they are highly migratory and the segregation/aggregations are coupled with generations of migrations across the oceans. This first attempt on the molecular identification of delphinids and finless porpoise of Indian seas has clearly indicated the need for studying more number of species and individuals; phylogenetic relationships to understand the evolution of different species; and genetic variation vis-àvis global geographic distribution of different species for the biodiversity conservation plans of these vulnerable/endangered animals.

\section{Acknowledgement}

The present study was funded by the Ministry of Earth Sciences, Government of India. We are thankful to the Director, CMFRI, Cochin for facilities and to the researchers Charles Scott Baker, Susan Chivers, Richard LeDuc, William Perrin, Patricia Rosel, Susana Caballero, Howard Ross, Nicky Wiseman, Thomas Jefferson and K. S. Mohamed for their useful suggestions and guidance at various stages during this investigation. Comments from two anonymous referees helped to improve the manuscript.

\section{References}

Amaral, A.R., Sequeira, M., Cedeira, J.M. \& Coelho, M.M. (2007) New insights on population genetic structure of Delphinus delphis from the northeast Atlantic and phylogenetic relationships within the genus inferred from two mitochondrial markers. Marine Biology, 151(5), 1967-1976.

Arnason, U. \& Gullberg, A. (1996) Cytochrome $b$ nucleotide sequences and the identification of five primary lineages of extant cetaceans. Molecular Biology and Evolution, 13, 407-417.

Baker C.S., Dalebout, M.L., Lavery, S. \& Howard, A.R. (2003) www. DNA surveillance: applied molecular taxonomy for species conservation and discovery. TRENDS in Ecology and Evolution, 18(6), 271-272.

Baker, C.S., Ross, H. Lavery, S., Rodrigo, A. \& Dalebout, M.L. (2004) Progress on an applied molecular taxonomy of cetacean species. In: Reeves, R.R., Perrin, W.F., Taylor, B.L., Baker, C.S. \& Mesnick, S.L. (Eds), Report of the Workshop on Shortcomings of Cetacean Taxonomy in Relation to Needs of Conservation and Management, La Jolla, California, pp 91.

Caballero, S., Trujillo, F., Vianna, J.A., Barrios-Garrido, H., Montiel, M.G. Beltran-Pedreros, S., Marmontel, M., Santos, M.C., Rossi-Santos, M., Santos, F.R. \& Baker, C.S. (2007) Taxonomic status of the genus Sotalia: species level ranking for 'tucuxi' (Sotalia fluviatilis) and 'costero' (Sotalia guianensis) dolphins. Marine Mammal Science, 23 (2), 358-386.

Dalebout, M.L., Baker, C.S., Steel, D., Robertson, K.M., Chivers, S.J., Perrin, W.F., Mead, J.G., Grace, R.V. \& Schofield, T.D. Jr. (2007) A divergent mtDNA lineage among Mesoplodon beaked whales: molecular evidence for a new species in the tropical Pacific?. Marine Mammal Science, 23(4): 954-966.

Dizon, A., Baker, C.S., Cipriano, F., Lento, G., Palsboll, P. \& Reeves, R. (2000) Molecular genetic identification of whales, dolphins, and porpoises: Proceedings of a workshop on the forensic use of molecular techniques to identify wildlife products in the market place. NOAA-TM-NMFS-SWFSC-286, 1-51.

Hall, T.A. (1999) BioEdit: a user-friendly biological sequence alignment editor and analysis program for Windows 95/ 98/NT. Nucleic Acids Symposium Series, 41, 95-98.

Hamilton, H., Caballero, S., Collins, A.G. \& Brownell, R.L. Jr. (2001) Evolution of river dolphins. Proceedings of the Royal Society, London, B, Biological Sciences, 268 (1466), 549-556.

Irwin, D.M., Kocher, T.D. \& Wilson, A.C. (1991) Evolution of the Cytochrome $b$ gene of mammals. Journal of Molecular Evolution, 32, 128-144. 
Jefferson, T.A. \& Waerebeek, K.V. (2002) The taxonomic status of the nominal dolphin species Delphinus Tropicalis Van Bree, 1971. Marine Mammal Science, 18(4), 787-818.

Kumaran, P.L. (2002) Marine mammal research in India - a review and critique of the methods. Current Science, 83(10), 1210-1220.

Leduc, R.G., Perrin, W.F. \& Dizon, A.E. (1999) Phylogenetic relationships among the delphinid cetaceans based on full cytochrome $b$ sequences. Marine Mammal Science, 15(3), 619-648.

Milinkovitch, M.C., Leduc, R., Tiedemann, R. \& Dizon, A. (2002) Applications of molecular data in cetacean taxonomy and population genetics with special emphasis on defining species boundaries. In Evans, P.G.H. \& Raga, J.A. (Eds) Marine Mammals: Biology and Conservation, Kluwer Academic/Plenum Publishers, London, UK, pp 325-359.

Mirol, P.M., Mascheretti, S. \& Searle, J.B. (2000) Multiple nuclear pseudogenes of mitochondrial cytochrome $b$ in Ctenomys (Caviomorpha, Rodentia) with either great similarity to or high divergence from the true mitochondrial sequence. Heredity, 84(5), 538-547.

Palumbi, S.R. (1996) Nucleic acids II: the Polymerase Chain Reaction. In: Hills, D. \& Moritz, C. \& Mable, B.K. (Eds.), Molecular Systematics. Sinaeur Associates, Sunderland, MA., pp 205-248.

Perrin, W. F. (1990) Subspecies of Stenella longirostris (Mammalia: Cetacea, Delphinidae). Proceedings of the Biological Society, Washington, 103(2), 453-463.

Perrin, W.F., Dolar, M.L.L. \& Robineau, D. (1999) Spinner dolphins (Stenella longirostris) of the western Pacific and Southeast Asia: pelagic and shallow water forms. Marine Mammal Science, 15, 1029-1053.

Perrin, W.F., Wursig, B. \& Thewissen, J.G.M. (2002) Encyclopedia of marine mammals. Academic Press, San Diego, California.

Reeves, R.R., Perrin, W.F., Taylor, B.L. Baker, C.S. \& Mesnick, S.L. (2004) Report of the Workshop on Shortcomings of Cetacean Taxonomy in Relation to Needs of Conservation and Management. La Jolla, California, $91 \mathrm{pp}$.

Rice, D.W. (1998) Marine mammals of the world. NOAA Technical Report NMFSSSRF-711, 15pp.

Rosel, P.E., Dizon, A.E. \& Heyning, J.E. (1994) Genetic analysis of sympatric morphotypes of common dolphins (genus Delphinus). Marine Biology, 119, 159-167.

Rosel, P.E., Dizon, A.E. \& Haygood, M.G. (1995b) Variability of the mitochondrial control region in populations of the harbour porpoise, Phocoena phocoena, on interoceanic and regional scales. Canadian Journal of Fisheries and Aquatic Sciences, 52, 1210-1219.

Rosel, P.E, France, S.C., Wang, J.Y. \& Kocher, T.D. (1999) Genetic structure of harbour porpoise Phocaena phocoena populations in the northwest Atlantic based on mitochondrial and nuclear markers. Molecular Ecology, 8, S41-S54.

Ross, H.A., Lento, G.M., Dalebout, M.L., Goode, M., Ewing, G., Mclaren, P., Rodrigo, A.G., Lavery, S. \& Baker, C.S. (2003) DNA Surveillance: Web-based molecular identification of whales, dolphins and porpoises. Journal of Heredity, 94(2), $111-114$.

Sambrook, E., Fritsch, F. \& Maniatis, T. (1989) Molecular Cloning: A Laboratory Manual. Cold Spring Harbour Press, Cold Spring Harbour, New York.

Sathasivam, K. (2004) Marine Mammals of India, University Press, Hyderabad, xxiii, 184 pp.

Shirakihara, M., Yoshida, H. \& Shirakihara, K. (2003) Indo-Pacific bottlenose dolphins Tursiops aduncus in Amakusa, western Kyushu, Japan. Fisheries Science, 69, 654-656.

Sutaria, D., \& Jefferson, T.A. (2004) Records of Indo-Pacific Humpback dolphins (Sousa chinensis, Osbeck, 1765) Along the Coasts of India and Sri Lanka: An Overview. Aquatic mammals, 30(1), 125-136.

Thompson, J.D., Higgins, D.G. \& Gibson, T.J. (1994) CLUSTAL W: improving the sensitivity of progressive multiple sequence alignment through sequence weighting, positions-specific gap penalties and weigh matrix choice. Nucleic Acids Research, 22, 4673-4680.

Yousuf, K.S.S.M., Anoop, A.K., Anoop, B., Afsal, V.V., Vivekanandan, E., Kumarran, R.P., Rajagopalan, M., Krishnakumar, P.K., \& Jayasankar, P. (2008) Observations on incidental catch of cetaceans in three landing centres along the Indian coast. Journal of Marine Biological Association UK 2 Biodiversity records, online publication (Ref no. 6254) pp.6. 